\title{
Biology and Management of Praxelis (Praxelis clematidea) in Ornamental Crop Production'
}

\author{
Yuvraj Khamare, Chris Marble, Shawn Steed, and Nathan Boyd ${ }^{2}$
}

\section{Introduction}

Praxelis clematidea is a newly emerging weed species in Florida, one that Plant Protection and Quarantine (PPQ) is considering adding to the federal noxious weed list (USDAAPHIS 2014). It was first discovered in an abandoned orange grove in Orange County, Florida, in 2006 (Abbott et al. 2008). The plant can be easily misidentified and confused with Ageratum houstonianum (bluemink) and Conoclinium coelestinum (blue mistflower) as well as several other species that have similar flower characteristics. This article is written for green industry professionals and others to aid in the identification and management of praxelis in and around ornamental plants.

\section{Species Description}

\section{Class}

Dicot

\section{Family}

Asteraceae

\section{Other Common Names}

Praxelis

\section{Life Span}

Annual or short-lived perennial.

\section{Habitat}

Praxelis grows in tropical and subtropical environments and is native to South America (Vedkamp 1999). It tolerates partial to full sun but does not grow well in fully shaded conditions (CRC Weed Management 2003). It is usually found growing in disturbed areas of roadsides, in pastures, along railway lines, in recently burned areas, in open woods, and along fence lines or streambanks (Waterhouse 2003). In the nursery, it grows in noncrop areas (walkways, aisles, dry ditch banks), on container media surfaces (in container-grown ornamentals), and in pot drain holes.

\section{Distribution}

Praxelis is native to Argentina, Bolivia, southern Brazil, and some other parts of South America (King and Robinson 1970). It has been introduced and become naturalized in China and Taiwan, and it is especially problematic in Australia, where it has begun invading natural areas as well as agricultural production fields (USDA-APHIS 2014). Praxelis has been documented in seven central Florida

1. This document is ENH1321, one of a series of the Environmental Horticulture Department, UF/IFAS Extension. Original publication date August 2020. Visit the EDIS website at https://edis.ifas.ufl.edu for the currently supported version of this publication.

2. Yuvraj Khamare, graduate research assistant; Chris Marble, assistant professor, Environmental Horticulture Department, UF/IFAS Mid-Florida Research and Education Center; Shawn Steed, multicounty environmental horticulture Extension agent III, Hillsborough and Polk Counties; and Nathan Boyd, associate professor, Horticultural Sciences Department, UF/IFAS Gulf Coast REC; UF/IFAS Extension, Gainesville, FL 32611.

The use of trade names in this publication is solely for the purpose of providing specific information. UF/IFAS does not guarantee or warranty the products named, and references to them in this publication do not signify our approval to the exclusion of other products of suitable composition. Use pesticides safely. Read and follow directions on the manufacturer's label.

The Institute of Food and Agricultural Sciences (IFAS) is an Equal Opportunity Institution authorized to provide research, educational information and other services

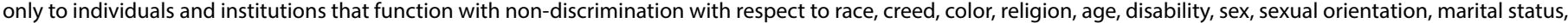

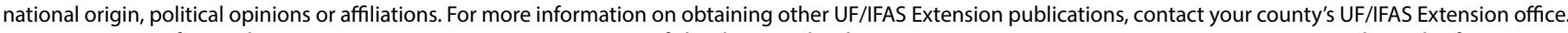
U.S. Department of Agriculture, UF/IFAS Extension Service, University of Florida, IFAS, Florida A \& M University Cooperative Extension Program, and Boards of County Commissioners Cooperating. Nick T. Place, dean for UF/IFAS Extension. 
counties (Hardee, Hillsborough, Lake, Manatee, Orange, Osceola, and Polk) (Wunderlin and Hansen 2014). This species is thought to have been introduced into Florida as a contaminant in commercial trade of seeds or possibly landscaping products, such as mulch and building materials (CRC Weed Management 2003). The predicted or potential distribution of praxelis includes most of the southeastern United States as well as Hawaii (USDA-APHIS 2014).

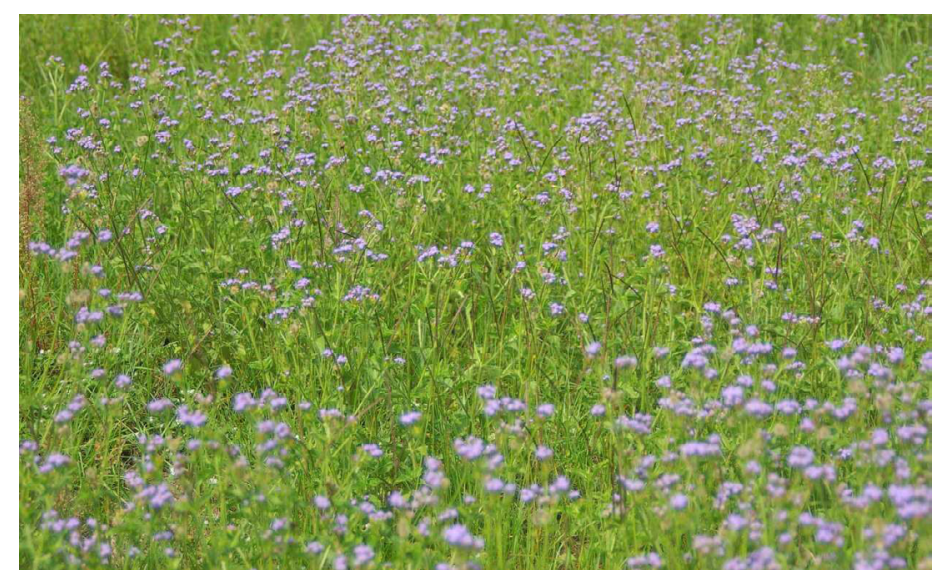

Figure 1. Praxelis clematidea growing in open field.

Credits: Annette Chandler, UF/IFAS

\section{Growth Habit}

Praxelis is an upright-growing herb that commonly grows to a height of 16-20 inches but has been observed growing as tall as 40 inches (Abbott et al. 2008).

\section{Seedling}

Seedlings are light green in color. The cotyledon (seed leaves) are hairy, are toothed along the leaf margins (serrated), and have noticeable midveins.

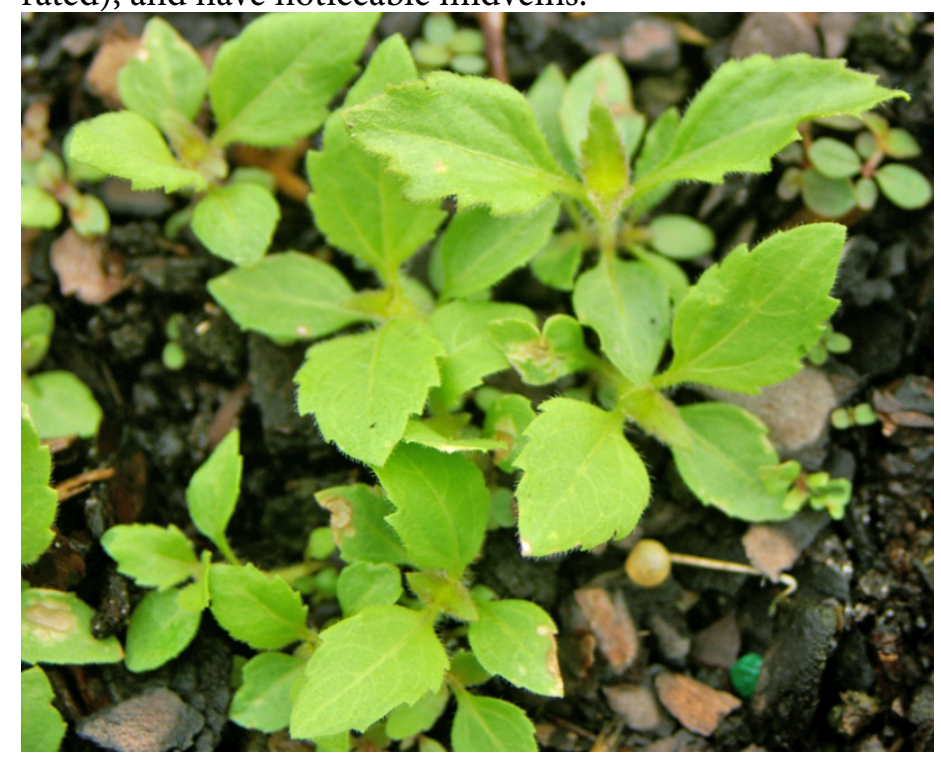

Figure 2. Praxelis clematidea seedlings.

Credits: Annette Chandler, UF/IFAS

\section{Shoots}

The stem is cylindrical, brittle, green in color, and covered in hair (pubescence). The leaves are hairy underneath, oppositely arranged, and approximately 1 to 2.5 inches long and 0.5 to 1.5 inches wide. The shape of leaves ranges from a tear to a diamond, and they have large-toothed edges with 5-8 large teeth (or serrations) on each side. One of the distinguishing features of praxelis is the smell of its leaves, which emit a foul odor like cat urine when crushed or after mowing (CRC Weed Management 2003).

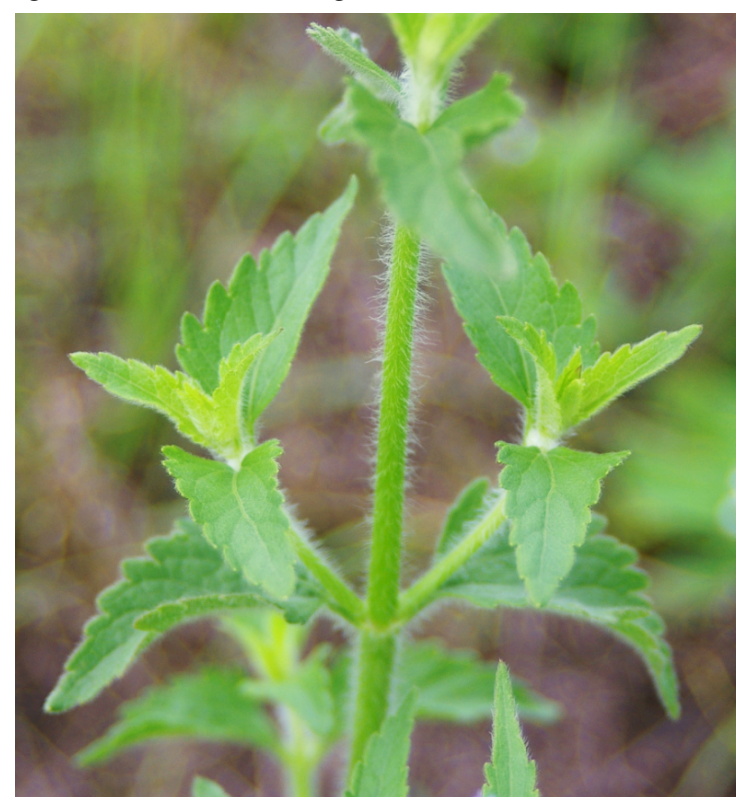

Figure 3. Praxelis clematidea stem covered in hair. Credits: Annette Chandler, UF/IFAS

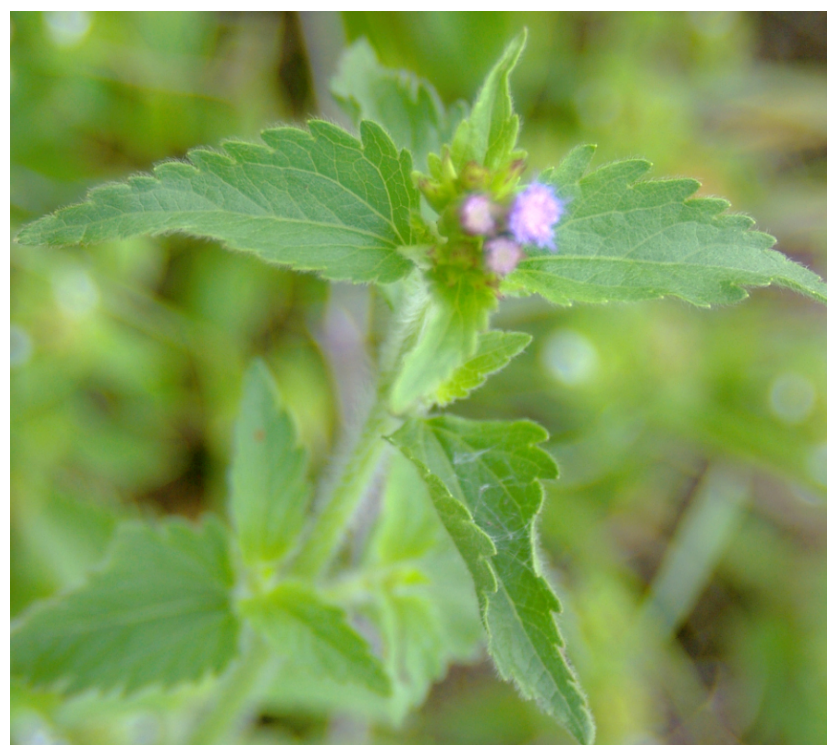

Figure 4. Praxelis clematidea leaves with large-toothed edges. Credits: Annette Chandler, UF/IFAS

\section{Roots}

Praxelis has a fibrous root system. 


\section{Inflorescence}

Praxelis has lavender- or bluish-colored flowers that are in clusters of about 35-40 tubular florets (tiny flowers) growing in groups at the ends of hairy stems. The key distinctive feature of praxelis is that florets are set into a highly coneshaped receptacle. Flowering mostly occurs from January to May, but plants have been observed flowering throughout the year in central Florida when winter temperatures remain mild (above freezing).

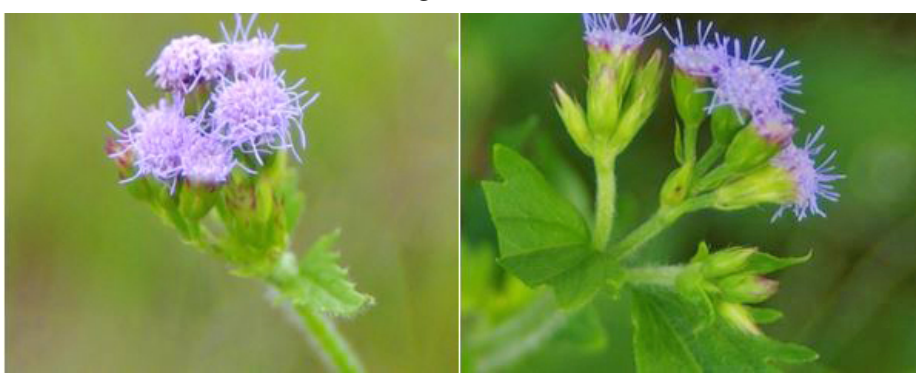

Figure 5. Praxelis clematidea in flower.

Credits: Annette Chandler, UF/IFAS

\section{Fruits and Seeds}

The seeds are black in color and 0.1-0.2 inches long. Seeds have a "pappus" or a cluster of barbed bristles (15-40 bristles) that can help them spread by wind or water, or by attaching themselves to animal fur and feathers, clothing, or machinery.

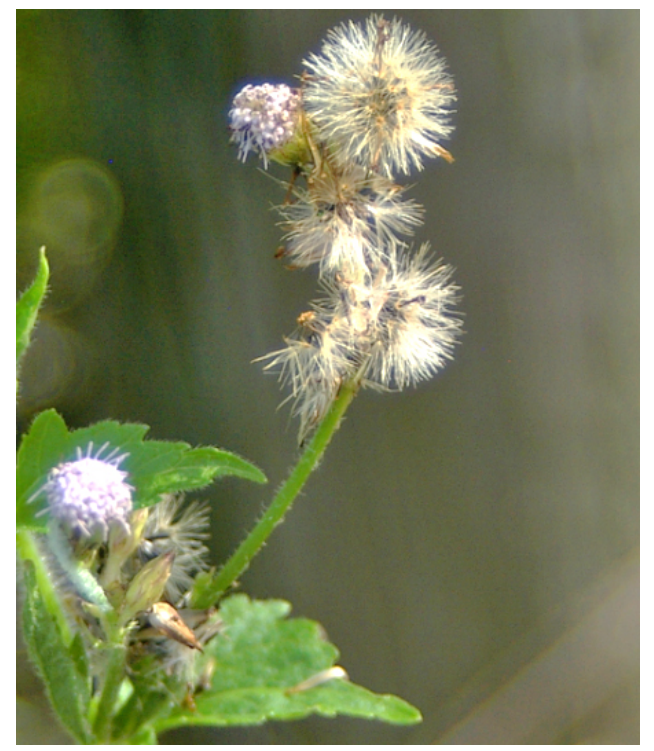

Figure 6. Pappus with seeds of Praxelis clematidea. Credit: Annette Chandler, UF/IFAS

\section{Similar Species}

Praxelis clematidea is morphologically similar to several other species in Florida, such as the native species Chromolaena odorata (Siamweed) and Fleischmannia incarnata (pink thoroughwort), and two other related exotic weed species, Ageratum conyzoides (tropical whiteweed) and
Ageratum houstonianum (bluemink) (CRC Weed Management 2003, Gardner and Williges 2015). This similarity and misidentification between praxelis and ageratum led to the unreported spread of praxelis in Australia and Hong Kong (Gardner and Williges 2015) for several years. It is probably the same reason praxelis remained unreported in Florida until recently (Abbott et al. 2008). The leaves in Ageratum houstonianum are broader and heart-shaped (cordate), and their finely or bluntly edged teeth on the leaf blade (Figure 7) are smaller than those of praxelis, which has more diamond-shaped leaves with larger teeth or serrations (Figure 7). The bract that surrounds and supports the flower head is persistent, unlike the corresponding bract in praxelis. The plant also lacks pappus, and seeds consist of four to five small, bristle-like scales. Ageratum littorale (Cape Sable whiteweed) and Conoclinium coelestinum (blue mistflower) are two other native species that look similar to Praxelis clematidea. Ageratum littorale and Conoclinium coelestinum tend to grow in sandy soils along the coast and prefer moist to wet soils.

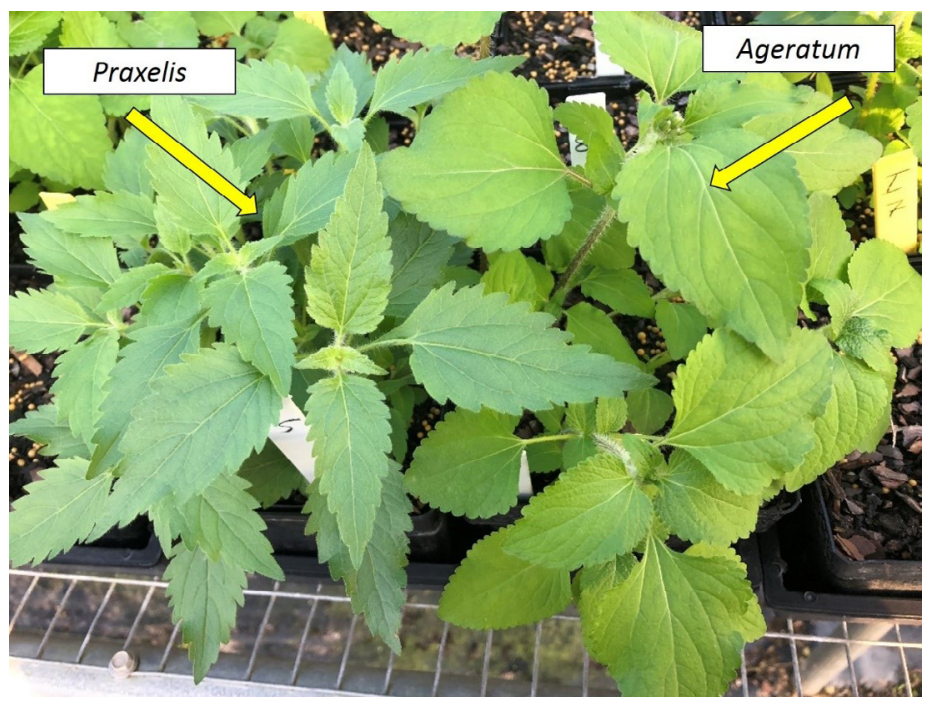

Figure 7. Differences between praxelis and ageratum leaves. Credits: Chris Marble, UF/IFAS

\section{Management Physical and Cultural Control}

In containers, praxelis should be hand weeded before it starts flowering. Each plant can produce thousands of seeds in a few months after germination. Scouting and regular hand weeding will prevent any further spread of the plant. In addition to hand weeding, the use of mulch such as pine bark, wood chips, rice hulls, or weed disks has proven to be effective on many weeds. In noncrop areas, such as walkways and aisles between container production spaces, mowing can reduce seed production and spread. 


\section{Chemical Control}

\section{PREEMERGENCE HERBICIDES}

Due to its relatively new emergence and the fact that it is currently only found in Florida, praxelis is not listed as a controlled weed on any preemergence herbicide labeled for use in nurseries. Research at the University of Florida has shown that preemergence herbicides, including oxyfluorfen + prodiamine (Biathlon), flumioxazin (Broadstar or SureGuard), and oxyfluorfen + pendimethalin $(\mathrm{OH} 2)$, provided excellent control of praxelis. A similarity among all of these products is that each contains a protoporphyrinogen oxidase (PPO) inhibitor (Group 14) herbicide as at least one of the active ingredients. Other herbicides that provided control or suppression were indaziflam (Marengo ${ }^{\circ} \mathrm{SC}$ ) and isoxaben + prodiamine $\left(\mathrm{Gemini}^{\oplus} \mathrm{SC}\right)$. Products that provided poor control include dimethenamid-P (Tower ${ }^{\circledast}$ and as a component of FreeHand ${ }^{\oplus}$ ) and isoxaben + trifluralin $\left(\right.$ Snapshot $\left.^{\circledast}\right)$. Preemergence herbicides that have been evaluated for control of praxelis are listed in Table 1 along with efficacy rankings for the rates that were evaluated.

\section{POSTEMERGENCE HERBICIDES}

The State of Queensland Department of Agriculture, Fisheries, and Forestry (DAFF) has recommended the use of herbicides such as glyphosate (RoundUp ${ }^{\circledR}$ Pro and many other trade names), fluroxypyr (Vista ${ }^{\circledR}$, metsulfuron-methyl (Escort $\left.{ }^{\oplus} \mathrm{XP}\right), 2,4-\mathrm{D}$ (many trade names), and picloram (Tordon ${ }^{\circledast}$ ) as potential options for praxelis control, but the effectiveness of these herbicides on praxelis has not been reported in the literature (DAFF 2014). It is also important to note that most of these active ingredients would only be labeled for use in noncrop areas and would not be options near ornamental plants. Research at the University of Florida has shown that herbicides including triclopyr $\left(\right.$ Garlon $^{\circledast} 4$ ), clopyralid (Lontrel ${ }^{\circledR}$ ), and glyphosate (Ranger ${ }^{\circledast}$ PRO) can provide $80 \%$ to $100 \%$ control for 12 weeks. Glufosinate (Finale ${ }^{\oplus}$ ) also provided control for 4 to 6 weeks, but regrowth and recovery was much more rapid, likely due to the limited translocation of glufosinate compared with the other herbicides that were evaluated. Due to the high seed production of praxelis, more long-term control would likely be achieved by combining the use of preemergence and postemergence herbicides to prevent regrowth from germination.

\section{References}

Abbott, J., C. L. White, and S. Davis. 2008. "Praxelis clematidea (Asteraceae), a Genus and Species New for the Flora of North America." Journal of the Botanical Research Institute of Texas 2:621-626.
Animal and Plant Health Inspection Service (APHIS). 2014. "Risk Assessment for Praxelis clematidea." https:// www.aphis.usda.gov/plant_health/plant_pest_info/weeds/ downloads/wra/Praxelis_clematidea.pdf. Accessed Nov. 12, 2019.

CRC Weed Management. 2003. "Weed Management Guide: Praxelis (Praxelis clematidea)." Cooperative Research Centre (CRC) for Australian Weed Management, Australia.

Department of Agriculture, Fisheries, and Forestry (DAFF). 2014. "Praxelis (Praxelis clematidea)." PP113. The State of Queensland, Australia. http://www.daff.qld.gov.au/_data/ assets/pdf_file/0019/63172/IPA-Praxelis-PP113.pdf. Accessed Oct. 24, 2019.

Florida Exotic Pest Plant Council (FLEPPC). 2014. "Praxelis clematidea." https://www.fleppc.org/list/2015/criteria_Praxelis_clematide.pdf. Accessed May 29, 2019.

Gardner, A. G., and K. A. Williges. 2015. "Praxelis clematidea (Asteraceae): A New Plant Invader of Florida." Southeastern Naturalist 14 (1).

King, R. M., and H. Robinson. 1970. "Studies in the Eupatorieae (Compositae). XXVIII. The Genus Praxelis." Phytologia 20:193-195.

Kumar, S., and C. M. Singh. 1989. "Control of Ageratum conyzoides L. under Mid Hill Conditions of Himachal Pradesh." Indian Journal of Weed Science 21:55-59.

Singh, C. M., N. M. Angras, and S. Kumar. 1996. Weed Management. New Delhi, India: MD Publications.

Veldkamp, J. F. 1999. “Eupatorium catarium, a New Name for Eupatorium clematideum Griseb., non Sch.Bip. (Compositae), a South American Species Naturalised and Spreading in SE Asia and Queensland, Australia." Garden Bulletin Singapore 51:119-124.

Waterhouse, B. M. 2003. "Know Your Enemy: Recent Records of Potentially Serious Weeds in Northern Australia, Papua New Guinea and Papua (Indonesia)." Telopea 10:477-485.

Wunderlin, R. P., and P. F. Hansen. 2014. Atlas of Florida Vascular Plants. University of South Florida, Department of Biology, Institute for Systematic Botany. http://florida. plantatlas.usf.edu/Default.aspx. Accessed June 7, 2019. 
Table 1. Preemergence herbicides labeled for use in ornamental plant production and evaluated for control of praxelis in Florida research trials*.

\begin{tabular}{|c|c|c|c|c|c|c|c|c|}
\hline $\begin{array}{l}\text { Common name } \\
\text { (active ingredient) }\end{array}$ & $\begin{array}{c}\text { Example trade } \\
\text { name and } \\
\text { formulation }\end{array}$ & $\begin{array}{l}\text { WSSA } \\
\text { Herbicide } \\
\text { Group' }\end{array}$ & $\begin{array}{c}\text { Rate } \\
\text { evaluated }\end{array}$ & Efficacy ${ }^{2}$ & $\begin{array}{l}\text { Container } \\
\text { production }\end{array}$ & $\begin{array}{c}\text { Field } \\
\text { production }\end{array}$ & $\begin{array}{l}\text { Greenhouse or } \\
\text { fully enclosed } \\
\text { structures }\end{array}$ & Landscape \\
\hline \multirow[t]{2}{*}{ flumioxazin } & Broadstar $^{\mathrm{TM}} 0.25 \mathrm{G}$ & \multirow[t]{2}{*}{14} & $100 \mathrm{lb} / \mathrm{A}$ & \multirow[t]{2}{*}{ C } & YES & YES & NO & YES \\
\hline & SureGuard $^{\circledR}$ 51WDG & & $12 \mathrm{fl} \mathrm{oz} / \mathrm{A}$ & & $\mathrm{YES}^{3}$ & $\mathrm{YES}^{3}$ & $\mathrm{NO}^{6}$ & $\mathrm{YES}^{4}$ \\
\hline dimethenamid-p & Tower $^{\circledast} 6 \mathrm{EC}$ & 15 & $32 \mathrm{floz} / \mathrm{A}$ & $\mathrm{P}$ & YES & YES & NO & YES \\
\hline indaziflam & Marengo $^{\oplus} 0.622 \mathrm{SC}$ & 29 & $15.5 \mathrm{fl} \mathrm{oz} / \mathrm{A}$ & $\mathrm{S}-\mathrm{C}$ & $\mathrm{NO}^{5}$ & YES & $\mathrm{YES}^{6}$ & NO \\
\hline $\begin{array}{l}\text { pendimethalin }+ \\
\text { dimethenamid-p }\end{array}$ & FreeHand $^{\circledast} 1.75 \mathrm{G}$ & $3+15$ & $200 \mathrm{lb} / \mathrm{A}$ & $\mathrm{P}$ & YES & YES & NO & YES \\
\hline $\begin{array}{l}\text { trifluralin + } \\
\text { isoxaben }\end{array}$ & Snapshot $^{\oplus} 2.5 \mathrm{TG}$ & $3+21$ & $200 \mathrm{lb} / \mathrm{A}$ & $S$ & YES & YES & NO & YES \\
\hline $\begin{array}{l}\text { prodiamine + } \\
\text { isoxaben }\end{array}$ & Gemini $^{\mathrm{TM}} 3.7 \mathrm{SC}$ & $3+21$ & $87 \mathrm{fl} \mathrm{oz/A}$ & $\mathrm{S}-\mathrm{C}$ & YES & YES & NO & NO \\
\hline $\begin{array}{l}\text { oxyfluorfen + } \\
\text { pendimethalin }\end{array}$ & $\mathrm{OH} 2^{\circledR} 3 \mathrm{G}$ & $14+3$ & $100 \mathrm{lb} / \mathrm{A}$ & C & YES & YES & NO & YES \\
\hline $\begin{array}{l}\text { oxyfluorfen + } \\
\text { prodiamine }\end{array}$ & Biathlon $^{\circledast} 2.75 \mathrm{G}$ & $14+3$ & $100 \mathrm{lb} / \mathrm{A}$ & C & YES & YES & NO & YES \\
\hline $\begin{array}{l}\text { *This table lists regis } \\
\text { office for additional } \\
\text { ufl.edu) } \\
\text { 'Herbicide groups a } \\
\text { Technology 17:605- } 6 \\
{ }^{2} \mathrm{P}=\text { poor control; } \mathrm{S} \\
\text { evaluated" column). } \\
{ }^{3} \text { Can only be used in } \\
\text { application method } \\
{ }^{4} \text { Can be applied as a } \\
\text { } \text { Marengo } 0.622 \mathrm{SC} \\
\text { Specticle } \\
{ }^{\mathrm{T}} \text { is labeleded for use on }\end{array}$ & $\begin{array}{l}\text { tered pesticides that sl } \\
\text { nformation (https://ifa } \\
\text { e based according to } \\
19 \text { [2003]) so as to min } \\
=\text { suppression, C = goo } \\
\text { selected conifer and c } \\
\text { directed application a } \\
\text { an be used in pot-in-p } \\
\text { for use in landscapes. } \\
\text { greenhouse floors only }\end{array}$ & $\begin{array}{l}\text { ould be inte } \\
\text { s.ufl.edu; “UF } \\
\text { rimary sites } \\
\text { imize the po } \\
\text { d control bas } \\
\text { eciduous tre } \\
\text { ound establi } \\
\text { th container }\end{array}$ & $\begin{array}{l}\text { grated with o } \\
\text { IFAS Locatior } \\
\text { ential for the } \\
\text { ed on rates th } \\
\text { species. Che } \\
\text { shed woody I }\end{array}$ & $\begin{array}{l}\text { ther pest ma } \\
\text { is" at the bo } \\
\text { can be used } \\
\text { developme } \\
\text { lat were eval } \\
\text { ck manufac } \\
\text { andscape or }\end{array}$ & $\begin{array}{l}\text { anagement me } \\
\text { ttom of the we } \\
\text { to select herb } \\
\text { nt of herbicide } \\
\text { luated in Univ } \\
\text { turer's label fo } \\
\text { namentals. }\end{array}$ & $\begin{array}{l}\text { thods. Contact } \\
\text { bpage). Contac } \\
\text { icides that have } \\
\text {-resistant weec } \\
\text { arsity of Florida } \\
\text { r a complete lis }\end{array}$ & $\begin{array}{l}\text { your local UF/IFAS } \\
\text { t: Weed Specialist } \\
\text { differing sites of } \\
\text { Is. } \\
\text { experiments (give } \\
\text { of species and re }\end{array}$ & $\begin{array}{l}\text { Extension } \\
\text { (marblesc@ } \\
\text { ction (Weed } \\
\text { n in "Rate } \\
\text { commended }\end{array}$ \\
\hline
\end{tabular}

Table 2. Postemergence herbicides and their efficacy for control of mature and flowering praxelis in experiments conducted in Florida*.

\begin{tabular}{|c|c|c|c|c|c|c|c|c|}
\hline $\begin{array}{c}\text { Common name } \\
\text { (active ingredient) }\end{array}$ & $\begin{array}{c}\text { Example trade } \\
\text { name }\end{array}$ & $\begin{array}{c}\text { WSSA } \\
\text { Herbicide } \\
\text { Group' }\end{array}$ & $\begin{array}{c}\text { Rate } \\
\text { evaluated }\end{array}$ & Efficacy $^{2}$ & $\begin{array}{l}\text { Container } \\
\text { production }\end{array}$ & $\begin{array}{c}\text { Field } \\
\text { production }^{3}\end{array}$ & $\begin{array}{c}\text { Greenhouse or } \\
\text { fully enclosed } \\
\text { structures }\end{array}$ & Landscape \\
\hline clopyralid & Lontrel $^{\otimes}$ & 4 & $1 \mathrm{pt} / \mathrm{A}$ & C & NO & YES & NO & YES \\
\hline glufosinate & Finale $^{\oplus}$ & 10 & $4 \mathrm{qt} / \mathrm{A}$ & $S$ & YES & YES & YES & YES \\
\hline glyphosate & Ranger ${ }^{\circledast}$ Pro & 9 & $2 \mathrm{qt} / \mathrm{A}$ & C & YES & YES & YES & YES \\
\hline triclopyr & Garlon $^{\circledast} 4$ Ultra & 4 & $2 \mathrm{qt} / \mathrm{A}$ & C & NO & NO & NO & NO \\
\hline
\end{tabular}

*This table lists registered pesticides that should be integrated with other pest management methods. Contact your local UF/IFAS Extension office for additional information (https://ifas.ufl.edu; “UF/IFAS Locations” at the bottom of the webpage). Contact: Weed Specialist (marblesc@ ufl.edu)

${ }^{1}$ Herbicide groups are based according to primary sites of action and can be used to select herbicides that have differing sites of action (Weed Technology 17:605-619 [2003]) to minimize the potential for the development of herbicide-resistant weeds.

${ }^{2} \mathrm{P}=$ poor control; $\mathrm{S}=$ suppression, $\mathrm{C}=$ good control based on rates (formulated amount of product applied on a per acre basis) that were evaluated in University of Florida experiments (given in "Rate evaluated" column). Herbicides were applied at an application volume of 50 gallons per acre and included adjuvants/surfactants based on label directions for each product.

${ }^{3}$ Container and field production refers to production areas only. Herbicides may be labeled for use in non-crop areas of these sites under certain scenarios. Check individual product labels.

${ }^{4}$ Clopyralid and triclopyr are not labeled for use inside greenhouses or enclosed structures under any circumstance. Glyphosate may be used in houses that are empty (containing no ornamental plants) while glufosinate can be used with crops inside the house. Read and follow all label instructions prior to use. 